\title{
Understanding the Causes of Electoral and Political Violence in Ekiti State, Nigeria: 2007-2010
}

\author{
BUHARI Lateef Oluwafemi PhD \\ Department of History and International Studies, \\ Faculty of Arts, Ekiti State University, P.M.B. 5363, Ado - Ekiti, Nigeria. \\ $+2348062468125$ \\ lateef.buhari@eksu.edu.ng,latfem4real@yahoo.com
}

\begin{abstract}
All over the world, elections are the litmus test of democracies. They also serve to consolidate political stability in a given polity just as they have the propensity to engender conflict and violence. Though there is usually competition over the control of the machineries of power, the turning point of that competition into violence becomes imperative in discerning the causes, both remote and immediate of such violence. In the light of the above, this paper notes the volatile nature of elections in Nigeria at large and Ekiti State in particular between 2007 and 2010. It examines plethora of factors leading to electoral fraud and political violence in the state. It further analyses the role of various stakeholders in political violence in the state.
\end{abstract}

Keywords: Nigeria, Politics, Election, Violence, Conflict, Ekiti State.

\section{Introduction}

The act of conducting election consists of several elements and stages that culminates and bring about a conclusive election in a particular locality or the state at large. The procedure for conducting a free and fair election include; the fair registration of political parties and eligible voters, accreditation of voters, the verification of the voters, conduct of poll, counting of voters, authentication or signing of result forms and the publication of results or declaration. Before an electorate is allowed to vote, his/her name must be in the register of voters; which is a document that contains the detailed names and particulars of voters, for each polling unit. The voters' register is compiled by the electoral commissions as provided for by the Electoral guidelines and electoral laws, this act must be carried out long in advance before the election period (Nigerian Electoral Act, 2006).

Elections are generally governed by domestic or municipal laws because the United Nations charter is based on the concept of sovereignty and the principle of non interference into domestic affairs of an independent country. The opinion of this research work is that notwithstanding anything, any form of democracy that does not bring stability, peace security and political and economic development is a complete failure while anything to the contrary should not be the 
concept and meaning of true democracy, ther4efore, the democracy imported from Europe to Asian and African countries yielded civil wars, poverty, economic stagnation, rigged elections, hunger and starvation, kidnapping, murder, killing, arson, etc has therefore woefully fell the test (Bujra and Adejumobi: 2003:3).

\section{Politics}

Odeyemi, described politics as 'a civilized means of organizing the society for the attainment of peace, equity and justices', he further noted that there is nothing in politics that make it negating or arithmetical to the peace, stability and well-being of the society. (The Nation, April 25, 2009:48). Meanwhile, politics is more basically seen from its negative attributes of violence, rigging and politically inspired arson and assassination (Ajayi, 2008:228-248). Ayinla (2005); refers politics to the art of governing a city. He explained further that a city here designate an organized and governed territory as a state under the jurisdiction of city. It is significant to note that it is the nature of a man to live in communities because he want to interact with its fellow men, to raise his standard of living and protect his own interests, so also does every other member of the community. Interest and needs of individuals in any community are sometimes identical, while at other time they conflict. He stated further that, politics concerns itself with the legitimate distribution of the good things of life that is socio-political and economic resources for the individuals, or groups and the scarce resources available in any community.

Lasswell (as cited in Ayinla 2005), defines politics as 'who get what, when and how. It is difficult for everyone in a society to get all his needs and desires without competition hence, politics is inherently a ferocious struggle for power. Those who struggle for political power often claim that they intend to use political power to create values for a society; for the best interest of the members of their society. Where people struggle for interest, influence and ultimate power at any level (domestic or international), violence and conflict as element of war thus exist.

However, politics is a term that seems unanimously understood by all. Hence, it is better described or explained rather than defining it. Politics involves- the study of principles and practices of political and institutional ideology of an organization or a nation state whether at domestic level or globally. Politics also involves other concepts like bureaucracy, power and power structure, power distribution and power sharing, and power control and regulation (Omolaja; 2003:120). Ajayi (2003:41); "politics is widely seen as means of becoming affluent. It is seen as a short -circuit to wealth. Besides, every contestant is also determined to rig the election in his own 
favour. And, where rigging is made impossible, violence, arson, kidnapping and murder of opponents are introduced into the electoral game. Electoral competition then becomes "a do-or-die affair".

Olufemi (2003); politics is a phenomenon that evokes a great deal of apprehension and uneasiness among ordinary citizens all over the world. In Nigeria, the popular perception of politics is that of a 'dirty game'. The perceptions stem from the unwholesome behavior of politician; their political maneuvers and manipulations; electoral malpractice; as well as trend towards violence and killings. The tendency therefore is for people to want to steer clear, as far as possible, of politics and politicians.

Yet, politics affects human lives in every available facet. Deutsch in Dipo corroborates this by adding that "societies have become webs of politics:

"The water we drink, the air we breathe, the safety of our streets, the dignity of our poor, the health of our old, the education of our young, and the hope of our minority groups all are bound up with the political decisions made at city all, (or) in the state capital. .. (Deutsch; 1974:3).

Therefore, politics is the essence of our social existence became our interactions with others in the society involves politics. And that no one can live in isolation of others. Ademola (2005:20); sees politics as a game of promises without fulfillment, and given the limited available resources to the system, certain individuals, groups and communities had their aspiration and expectations raised without the possibility of their being fulfilled.

\section{Violence}

According to Galtung (1991:10-12); violence could be physical, psychological and structural, physical violence is a situation where there is a physical assault, intimidation, whether mild or hard. Physical violence includes the kind of badly attack politicians or the supporters inflicts upon one another at party conventions, during political campaigns, during elections and when election results are release, it also includes the kind of attacks security agents inflict on members of the public or that numbers of inflict on law enforcement agents, on one another and INECofficials. Galtung characterizes the second type as psychological violence. This type of violence manifests in terms of citizens living, in a state of perpetual fear or intimidation of what could happen to them as a result of their involvement in elections and political activities. This type of violence explains the issue of political apathy in a society. In some cases, they are afraid of 
coming out to contest or vote. This kind of violence frustrates the excuse of conventional and unconventional political participation rights. Over time, non- participation in politics as a result of fear taken on the semblance of indifference, and this condition gets to be described as political apathy.

Political participation, this is refers to the extent to which individuals can form associations to defend and promote their interests in the society. Conventional participation refers to the right to vote and be voted for; attends political meetings, initiate political discussions, and; expose oneself to democratic political activity. While unconventional participation refers to the right to challenge or defy established institutions or the dominant culture in a political party or system. The party structure and leadership in Nigeria does not have a vacuum for this kind of political participation. A few powerful people simply control or monopolize the party structures and system and exclusively decide who does and gets what. Those who try to challenge this arrangement are either forced out of the political party or made to face the consequence or losing their lives. This pattern creates fears in a society and should be taken into consideration when mapping the state of electoral and not just political violence in a society.

The problem of (electoral) psychological violence becomes an issue of great significance in a country where the police find it difficult to assure citizens of what is technically known as "electoral security". According to Fischer, as cited in Albert (2003: 128)

the process of protecting electoral stakeholders such as voters, candidates, poll winners, media and observers; electoral information such as vote results registration data, and campaign materials, electoral facilities such as polling stations and counting centers; and electoral events. Such as campaign rallies against death, damage or disruption.

These bodies expected to provide this kind of security include security agencies, political parties, INEC, judicial officials and the media.

\section{Causes of Election and Political Violence in Ekiti State}

This paper presents the findings carried out in the course of this study. This research work was aimed at those factors that led to the electoral violence in the 2007 gubernatorial and State House of Assembly Elections in Ekiti State. Also, to know the extent at which the youths were involved in the violence; are focus of the study.

This research work was carried out with the use of in-depth interviews, Focused Group 
Discussion, Key In-depth and some National Newspapers as sources of information or data collection. The age distributions of respondents were those of 18 years and above as at April, 2007. The educational levels attained by the respondents were varied. They included unlettered people, those that attained primary school educational level, those with secondary education, those with university or other tertiary institutions; constitutes of the respondents. Note that those referred to as unlettered were those without any formal education, while some did not specify their educational background. The occupation of the respondents include; artisans i.e. Drivers' unions, carpentries, roadside mechanics, market men and women, etc. Others include Students 'unions, youths' associations, motorcyclists, and farmers in some localities etc. The religion of these respondents includes; Islam, Christianity and traditional or indigenous believers in Ekiti State.

\section{Factors responsible for political and electoral violence in Ekiti State, 2007 - 2010}

It was discovered that there various reasons why the people of Ekiti State reacted to the conduct of April 14, 2007 and the April 25, 2009 re-run elections. Some imminent people and groups in Ekiti state interviewed were of the opinion that electoral violence in Ekiti State started since the impeachment of the former Ekiti state governor, Ayo Fayose in the 2006 and that many factors were responsible for electoral violence in Ekiti State. These include:

\section{Greed and Grievances}

This factor was been referred to as "Greed and grievances" and the interest of the godfathers and their followers. A group of political analysts (newspapers or vendors' stand) around Fajuyi Park, opposite Ekiti State High Court claimed that Okada men were the major supporters of the exgovernor and they were told to support and attend rallies, organized by Fayose in the state. The Okada men at post-office area had this to say:

Ayo is our man, he is the father of all, he told us not to support

Segun Oni who came third in the PDP primary elections. Instead of Segun Oni we were asked voted for AjindeEkiti (YinkaAkerele) and Dr. FayemiKayode, AC, and we cannot allow Segun with stolen mandate.

Ayo Fayose, the impeached governor, intended to go back to government house, Ekiti State but the PDP leaders who suffered under the Fayose led administration disallowed him and his candidates to become a flag bearer of the party because they wanted to be in control of the party and the governance of the state. It was also gathered that the formal president, OlusegunObasanjo declared a state of emergence immediately after the impeachment had been carried out successfully 
by the members of the State House of Assembly who were all PDP members. This led the state to serious tensions, political and social unrest despite the imposition of emergency rule under General Olurin (Rtd). In addition, the political umpires, wanted by all means to win the elections because they wanted to be relevant to control the state's resources, power; he submitted that:

"Greediness on the part of the politicians, party faithful, and their followers would do anything humanly possible to either get selected as party candidate, win election at all cost, and consolidate power through constant harassment, victimization and intimidation of oppositions".

According to Falana;

" ... the tragedy of what took place in Ekiti State becomes manifest when leaders who were victims of the high- handedness of the Ayo Fayose now turn round to become the new tormentors and terrorists all over the place" (The Nation, Wednesday, May 22, 2007).

While 'showing his 'grievances' to the people of Ekiti State, Ayo Fayose (ex- governor); rejected Segun Oni and the PDP in totality, the impeached governor claimed that: the mistake of Oni's emergence as a governor at the April 14, 2007 elections has brought them (people) untold suffering". He urged the people of the state to cast their votes for the Action Congress (AC) candidate Fayemi. Fayose, attributed the problem dogging Oni's ambition as the alleged fraudulent manner in which Oni emerged as the Peoples Democratic Party (PDP) candidate at the party primaries stressed that many party members were 'aggrieved' by the alleged imposition of Oni by former President OlusegunObasanjo on them. According to him:

" ... that is why Oni is hated by party members and the majority of the People of the state (Yinka) Akerele and (Adesegun) Ojo came first and second respectively at the primaries but Oni's father at Otta (Obasanjo) prevented a run-off between the two and imposed his stooge on the party. (Ayo Fayose, the Nation Saturday, March 28,2009).

The above factor showed that the electoral and political violence started among the aggrieved PDP members in Ekiti State which later transferred to the Action Congress during its own party primaries' elections where the Ex-governor, Adeniyi Adebayo presented Dr. KayodeFayemi and declared him the flag bearer of the party. This led the other 14 gubernatorial candidates who defected to the PDP and posed many threats to AC members.

\section{Poor Electoral Administration}


It is murderer that they now want support from (The Nation Sat. March 21, 2009:48). Another factor mentioned and discussed was the issue of "poor electoral administration". Electoral administration constituted one of the factors that lead to electoral violence in Ekiti State before, during and after the April 14 and 25 April elections (2007 and 2009 rerun elections).

An in-depth interview with some members of a group named G-12, Ado-Ekiti claimed that the role played by the INEC from the registration period was not to write home about in Ekiti state.

According to them:

"INEC was not able to display the voters' registration list before the election as stipulated by the law. Voters did not have access to their lists on time for verification. This destroyed the faith of many people on the process. The used of DDC machine was mere waste of resources because it did provide good results".

This group condemned in totality the conduction of the voters' registration for the 2007 general election which they claimed that did not yield any result. They also condemned the conduct of the April 14,2007 and the re-run of April 25, 2009, elections in Ekiti State by the INEC staff and its leadership. According to this group;

"INEC in Ekiti and Nigeria at large has not been given the free hand to conduct the elections at its own will and discretion. INEC became a department under Obasanjo who controls its staffing and finances, INEC's operations ultimately subjected to the control of the PDP which was highly interested in the outcome of the elections".

The group blamed the presidency under Obasanjo who appointed the Senior officers of the commission i.e. partisan political appointees, they also blamed that the late release of funding to the INEC compromised the body's administrative and logistic capacity significance things has not been done to amend this ugly situation. Also, people at various stages such as drivers, motorcyclists, students and politicians were said to had disappointed on the way and manner in which INEC conducted the elections in Ekiti state which lead to rerun, tensions, chaos, social unrest and it lead to a psychological, structural and physical violence in the state. Students' leaders of the Federation of Ado-Ekiti students' union described the 2007 election in Ekiti State "as the insincerity on the part of electoral officers in which one can easily attribute to a source of political conflict in Ekiti. According to the formal president of the union during the discussion;

"the conduct of the 2007 elections and the rerun elections was a tactics used by the PDP and the INEC which made it cleared that not only the INEC was not effective but determined to set the state on 
fire; because the system sued by the INEC instigated the AC supporters to trooped to the streets in a protest, calling on INEC to declare Fayemi the winner. This action forced many civil servants and traders to hurriedly close their offices and shops in Ado-Ekiti, the state. capital".

Also, the motorcyclists' Association, Adebayo Area Branch, Ado-Ekiti, condemned the ill treatment of INEC which placed much tension on the people they said that it got to a stage when the two parties went to the streets jubilating undeclared victory. They said; "there was drama in Ado-Ekiti as PDP supporters trooped to the streets jubilating their imminent victory. Their AC counterparts also did same. After jubilation, accusations and counter accusation started with PDP members accusing Adebayo (Ex-governor) of being used the AC to scuttle the election". In an interview with some Action Congress Chieftains in Efon and Aramoko Local Government Areas on the role played by the INEC on 2007 and 2009 elections in Ekiti State; they did not hide their feelings, they said:

"INEC immorality was showed in many ways, they worked 'hand-inhand with the PDP led administration in the state, they refused to release materials on time, the electoral environment was very hot for the oppositions' parties and their supporters. At times some of our agents would say, we do not see INEC officials at some polling units and later you discover that election had started".

However, former president Obasanjo even accepted that there were irregularities in 2007 governorship and House of Assembly elections, he hope that by the time of the Federal polls, those omissions and errors would have been rectified (Nigerian Tribune, Monday 23 April, 2007).

On the other hand, the Ekiti Democratic Coalition Alliance (EDCA), gave an ultimatum to the then inspector general of police (IGP) Mr. Sunday Ehindero to arrest and prosecute Iwu, the Chairman, Independent National Electoral Commission over alleged electoral crimes against the Nigerians. Mr. Ogele, expressed dismay over Obasanjo's statements that the elections would be a do-or-die affair; it was noted that INEC acted the do-or-die script to the letter. It said in other societies, Iwuwould have been arrested for allegedly facilitating an unprecedented electoral fraud against the fellow countrymen.

According to him:

"we give Inspector General of police seven days within which to arrest Prof. Iwu for involving himself in election rigging, alteration of results, illegal disqualification of candidates, willful omission of 
some candidates' pictures from the ballot papers, deliberate shortage of ballot papers and criminal alliances with the police, military and the presidency" (The Nation Tuesday, May 15, 2007. The Nation Friday, March 27, 2009).

\section{Electoral Rigging}

Another factor that lead to election and political violence in Ekiti State was been referred to as 'electoral rigging'. It is a truism that this particular phenomenon had become a significant form of electioneering in this nation, the degree and methods adopts to achieving this had continued to evolve over the time. At Ward II of Ido-Ajinare, PDP chieftains on the entourage of the acting governor violently snatched ballot boxes from electoral officers and thumb printed some in favour of the PDP: according to the source:

" ... When they discovered that journalists were around, they attempted to seize the camera of a NAN photographer who took pictures of the person snatching ballot boxes from the female electoral officer attached to the centre, and who had vehemently cried out that she would not succumb to any rigging plan" (Nigerian Tribune, 30 April, 2007).

In an interactive-group discussion at PDP secretariat in Ado-Ekiti, Ekiti State capital, the PDP leaders and some members disclosed that there were series of violence and snatching of ballot boxes by opposition parties; In Ado-Ekiti and IkereEkiti, they claimed that AC and ANPP coalition helped by members of the strike squad of the Ayo Fayose, perpetrated mass rigging.

They said;

... they used fake mobile policemen, at a point, former Deputy Governor, Chief AbiodunAluko and his household were molested and prevented from leaving their homes on the Election Day".

At Okeyimi roundabout, a popular Newspapers joint in Ekiti State, the issue of electoral rigging arrested the minds of many people who could be regarded as political analysts; in the course of the discussion, it was gathered that in Ado-Ekiti, Action Congress unleashed violence on PDP members, day light stealing of materials, INEC was alleged to had announced or released uncompleted results in which the PDP members protested the outcome of the results in Ado-Ekiti, and Ikere-Ekiti. The ruling party challenged the cancellation of these results, both the gubernatorial and the House of Assembly; the two constituencies were won by the two AC candidates (DavidsTaiwo and Olanipekuna.k.aTugere). 
The party-condemned Ola who organized a press conference to rally support for the ruling team. Ola also made unlawful arrest of Some Action Congress and National Conscience party (NCP) members, refused to prosecute PDP members charged with various crimes, failure to withdraw police orderlies from PDP members and others during elections.

There were various comments from different quarters on the performances of the Commissioner of Police who made Ekiti state a safe haven for political thugs and hoodlums to perpetrate their evil at without check, or investigation whenever they commit atrocities. He did not enjoy the confidence of the people. The failure of the security agencies in the country and Ekiti State in particular had led to the increase in political violence which was perceived as a major cause of the 'leakage' of small arms into the hands of unauthorized persons. There was also extensive smuggling and the incidence of mercenary involvement.

\section{Political Intolerance:}

Some group of people in different locations attributed the causes of political and electoral violence in Ekiti State governorship election in April 14, 2007 and the April 25 re-run elections that was ordered by the Appeal Court in Ilorin as a result of the political intolerance among the political leaders, their followers, and their supporters or alliances. In a situation whereby people of the same party could not accept in their party primaries and defected to another party, definitely he/she would be looking at his/her formal party as enemy then they result to violence. They also cited example of some people in Ekiti who would reveal a mind that savours the ability of members of his community to engage in intense confrontation with power that be. This he would translate to mean a show of uprightness, outright boldness and unwillingness to cave-in to malevolence. He would remind you as if it is a natural to do so, that "Ekiti does not take none-sense from anybody". They concluded that "watchers of the campaigns need no special grace to understand that the two parties involved do not mean well for the people of Ekiti state. While the Action Congress with its slogan "Rig and Roast" spent much time reminding the people about the massacre of 1983 and the possibility of its resurgence in the 2009 re-run elections, the Peoples Democratic Party used its own time on the podium to slander the character of the former governor of Lagos State, Bola Tinubu. Throughout the campaign, none of the parties mentioned what it has in stock for common man and actions to be taken to ameliorate his suffering. In order to achieve a violent-free election, there must be a proper value orientation among politicians so that election could be see not a game 
of war, do-or- die affairs and something that must be won at all cost. Abe and Others made it cleared: 'the inability to recognize and accommodate view and opinions of others was therefore, one of the major causes of political violence. Politicians have demonstrated intolerant attitudes which resulted to violence in Ekiti State.

\section{Poverty and Unemployment}

In a comprehensive interview conducted with some groups in Ado-Ekiti, Ijero, Omuo, Otun and Ido-Osi Local Government Areas, it was reveal that poverty was a major factor that responsible for the influx of people from different location or localities into Ekiti because many of these people were jobless and what some earns for leaving in their places of work could not survived them. In "Ekiti there is no job, no company, or industries, all that we have is people building hotels and filling stations here and there". What these people were talking about was that people came down to Ekiti though some were indigenes while some were friends, relatives, etc. to some of the contestants; and these hoteliers and the owners of the filing station were (are) only recruiting secondary school leavers, the highest qualifications were (are) Ordinary National Diploma (OND), with token amount ofN5, 000 and N6, 500 respectively (Focus Group Discussion and In- depth Interviews). Similarly, another group of elites related the issue of poverty in the state to the low

productivity in agriculture; and the economic stagnation that the Nation had experienced for decades. This has great impact on the people of Ekiti land to increase their income. (Nigerian Tribune, Wednesday 11 April, 2007:7).

Other causes of political and electoral violence which were discussed during the field works includes: godfatherism, poor leadership, reprisals, emergence of corrupt political leaders, etc.

\section{Involvement of the Youth in the Electoral Political Violence in Ekiti State}

The results of the interview conducted showed that some youths' organizations were being peaceful (hot peace) in their approaches while some were being violent to the electoral processes in the state since late 2006 until 2010 and beyond. Though, those groups that were said to be peaceful (hot peace) used media propaganda to force or apply a psychological violence so that the party in control of the state could quickly adjust.

One of the groups that involved in this electioneer process was the Ekiti Youth Democratic Movement (EYDM). It uncovered many plans by the political parties that colluded with the monarchs in the state used their palaces as polling centre or units. Members of this organization alleged that a secret meeting was held by some monarchs with a top official of the Segun Oni 
administration during which the monarchs allegedly agreed to make their palaces available for riggers'. For this illegal venture, the group claimed that a huge sum of money was set aside.

The youth made these words:

"we call on the affected traditional rulers to desist from the plan to aid the PDP to rig the election or risk being molested by the people, should they go ahead to execute this plan". The Nation, Monday 16, 2009.

These groups of able-bodied youths were served as watch-dog in Ekiti State politics. This was realized in the course of the Focus Group Discussion, in-depth and key in-depth interview conducted with the PDP, AC, ANPP, Human Rights Organizations (CDHR), and some prominent indigenes of Ekiti. Though, the PDP leaders in the state described these groups as partisan politically motivated and an affiliate of Action Congress (AC). They also claimed that their major sources of incomes were from the Action Congress party and their leaders.

In the same way, some members of NURTW and Ado-Ekiti Student's Union, interviewed differently (about 15 members each) were opined that lack of employment among the youths in addition to quest for money were responsible for the youth involvement in election and political violence in the Ekiti state. Similarly, some respondents who are members of the ALUMNI, Ekiti State University, Ado-Ekiti, were of the views that most of the youths are over ambitious, in the sense that; "you see many of them wanted to contest for the position of the number one seat in their various schools EKSU, Ado Poly and College of Education, Ikere-Ekiti". This group with educated men and women were saying that; it is not only the politicians that employed the youths; the youths also approached them for political help. Therefore, they commit offence in the name of their mentors. This group explained the involvement of the youth in the attack made on the gubernatorial candidate of the PDP in December, 2006 at the palace of Olunyin in Irepodun/Ifelodun Local Government Council, the home town of the Ex-governor, Adeniyi Adebayo. The PDP candidate, Engr. Segun Oni and his running mate, Dr. SikiruLawal were narrowly escaped in the hands of the youth of the community in their preparation for the April 14, 2007 elections.

Findings revealed that larger parts of Ekiti State have experienced incidences of election and political violence very often while in some localities it was said to be often. This means that a larger part of the state including the respondents had experienced electoral violence.

The socio-economic backgrounds of the youth involved in electoral violence in Ekiti State 
Some respondents comment on the extent at which the youth socio-economic background could cause their involvement in elections and political violence. The issues of age, sex, level of education and duration of staying were been considered. According to the respondents, most of the youth that were fully involved in elections and political violence in Ekiti state were either jobless or unemployed people with Ordinary National Diploma Certificate (OND), Higher National Diploma Certificate (HND) and some University graduates. Also, they made mentioned of some secondary school learners whom could not further into higher institution of learning simply joined politics at his/her early stage of life. Again, according to one these respondents, he said it is very rear among the contemporary youths in Ekiti to have those who do not attend formal education at all; though there were some 'early school leavers' among them whom are members of one artisan or the other.

Another groups of respondents (market men and women) proved that many among these youths that were involved in elections and political violent acts had lived longer in Ekiti land because some of them were either former students of the Ekiti State University, Ado- Ekiti, Federal Polytechnic Ado-Ekiti or College of education, Ikere, etc. While a group of chiefs (5, in the palace, Ado-Ekiti) said that majority of these youths that had involved themselves in the act of political thuggery were being imported from the neighbouring states namely; Osun, Ondo, Kogi, Edo, Delta, Lagos, Oyo States, etc.. Citing copiously from Afe-Babalola, a legal luminary: attributed the spate of insecurity to unemployment and poverty. A situation whereby there is no development in a state, there will be unemployment. When we have unemployment, there will be hunger, when there is hunger; people do all sorts of things. Most of the boys who are kidnapping are graduates. Young graduate and why are they doing so, they are doing so because some of them after their parents have struggle to train them in Universities they have no employment and they resorted to kidnapping those whom are rich (Afe; the Nation Monday, March 14,2011).

However, one of the JDPCobservers, Dr. AzeezOlaniyan who monitored election alongside other three JDPC observers including Dr. AbubakarMomoh; responded and made various observations or comment on the conduct of the youths in Ekiti. He condemned the ways and manner the youths of IfakiEkiti, home town of the ousted governor Segun Oni bombarded them with cutlass, broken bottle, gun, all sorts of weapons. He added that because Abubakar was their (observers) spokesperson, these youths beat him up and smashed a bottle on his head. He also added that the policemen, about four of them at the check point could not do anything to protect them, 
"all these were done to us with the hope of the youths that we were sent by Asiwaju Bola Tinubu from Lagos". Citing copiously from AbubakarMomoh;

" ... youths from Ifaki, about 800 of them, came marching towards us. As each of them was taking his pound of flesh, they kept saying: 'let us kill them, let us kill them, get them off our way'. I could not even know what was happening to some of my colleagues. They kept beating us as they took us to Ifaki police station. One Hon. LanreFayemi ordered people to beat us. He was taking all sorts of phone calls, asking who to call. Before you know it, a crowd of over 3,000 Ifaki youths, men and women, young and old, had gathered. They wanted to burn the police station. Even Hon. Fayemi was saying that he would bum all of us with the police station before one MOPOL officer, Chief Superintendent of police, Samuel Etaifo-Erale came in. he called for reinforcement of policemen from headquarters" (The News, May 18, 2009:26-27).

Abubakar added that:

During the governorship election re-run in Ekiti State, thugs of people's Democratic Party and even the police turned the state into a veritable battle ground. Journalists and election monitors were targeted. They were in most cases seen as "spies" of Action Congress ... It was like going to hell and returning safely" (Ibid).

Over sixty youths were arrested in Senator Ayo-Arise's house at Oye Local Government Area; they detained along with the JDPC election monitors at the police station. Dr. Olaniyan said if not for the timely intervention of Samuel Efaifo (MOPOL), these youths would have wasted their lives, with over 3;000 youths waiting to carry out that mission. However, in view of this, it was revealed that over 70 percent of the youths were highly participated and involved in act of election and political violence in Ekiti State - 2007 - 2010 elections.

\section{The Effect of the Electoral Violence in Ekiti State}

Evidence from the field work or research has shown that electoral violence had great effects on the people of Ekiti State. This ranges from loss of live property, kidnapping, intimidation, etc. Innocent souls have given away their lives unwillingly to electoral violence which engulfed Ekiti State before 2007 elections, re-run election and during the tribunal cases or judgments.

\section{Social Unrest and Insecurity}

Electoral violence had led to several disturbances in the state. During elections, the level of insecurity deterred the electorate to cast or choose their representatives of their choices. The 
insecurity also discouraged respective investors that intended to develop the state. There was no guarantee for safety of lives and property. This phenomenon had a great setback in the economy of Ekiti State.

\section{Hostilities and Discord}

The level of hostility and discord among the party members, inter-political parties, monarchs, union (s), students, religious, youths, (partisans) etc. characterized by killings, kidnapping, mayhem, etc, instead of unity. The aggrieved members of political members and the various groups who were victims of the political violent activities were being hostile and engaged in reprisal attack on one group or the other even,' individuals. All these needless hostility, discord, chaos, attack, etc impacted negatively on the political system of Ekiti State.

\section{Political instability}

It is axiomatic that development cannot occur with the presence of political crises and instability. Ekiti State has five governors between 2007 and 2010. These includes: Sole Administrator Emergency rule 2006-2007), Segun Oni, May. 2007, January 2009, Segun Oni quit by the judgments of the Appeal Court in Ilorin, to handover to the speaker State House of Assembly. After 90 days, governorship re-run election took place and Segun Oni was given a certificate of return; he also took another oath of office. And finally, Segun was thrown out of office at Appeal Court in Ilorin in 2010 after which Dr. KayodeFayemi was not certified with outcome of the re-run election of April 25, 2009. On October 16 ${ }^{\text {th }}$ 2010, Dr. KayodeFayemi became the democratically elected Governor of Ekiti State. Since 2007, there was no meaningful development has taken place in the fifteen-year old state with many governors.

The effect of electoral violence is that it has helped propagate the act of violence in Ekiti State. This impacted negatively on the youths in the state. Youths were used as political thugs, hoodlums, as well as armed robbers. Many of them had become professional assassins. They were the instrument of violence in the state. A lot of weapons were found in the possession of these youths who had over the years become restive, taking undue advantage of porous nature of the security outfits of the state. These entire scenarios had undermined the manpower and development of Ekiti State. 


\section{References}

Ademola Azeez (2005): Political Violence in Nigeria: Implications and Options for Democratic Consolidation: in issues in political violence in Nigeria, Hamson printing Communication. Ilorin

Ajayi Kunle (2006): Security Forces, Electoral Conduct and the 2003 General Elections as Nigeria: In Journal ofthe Social Sciences 13(1).

AyinlaSaaduAlanamu (2005): "violence and politics in Nigeria (1999-2003)": Evidences from Kwara State; in Issues in Political Violence in Nigeria.Hamson printing Communication, Orin.

Ayinla, S.A. (2005). An Introductory Note "in Ayinla 'Saadu A (2005 ed); Issues in Political Violence in Nigeria,Hamson Printing Communication, Dorin, Nigeria.

Bujra, A. and S. Adejumobi (2003): Breaking Barriers, Creating New Hopes: Democracy, Civil Society and Good Governance in Africa.

Deutsch, W. Karl (1974), Politics and Government: How People Decide their Faith, Boston, HeughtonMitiflin Company.

Emmanuel Ojo (2007). "Elections: An Exploration of the Initial Population", in Journal of African Election, Special issue: Nigeria's 2007 General Elections. Global Print Johannes Burg, South Africa.

Kunle Ayayi (2003).Problem of Democracy and Electoral Politics in Nigeria, Issues in Nigerian Government and Politics, Dekael Publishers, Ibadan.

Muhammed Omolaja (2003). Administrative Politics in Africa: Implications for Development in International Review of Politics and Development. Vol. 1 No.1, January, 2003.

Victor, A.O, Adetulal (2008). Electoral Act 2006, Civil Society Engagement and the Prospect of Political Finance Reform in Nigeria", in Victor A.O. Adetula (ed) Money and Politics in Nigeria, International Foundation for Electoral System, IFES- Nigeria, Petal Digital Press, Garki, Abuja.

\section{Newspapers / Magazine:}

\section{The News}

May 18,2009 
The Nation

May22, 2007

May 28, 2009

March 21, 2009

May 15, 2007

May 16, 2009

March27, 2009

March 14,2011

Nigerian Tribune

April 23, 2007

April 30, 2007

April 11, 2007

The News May 18, 2009 